\title{
Biology of the Black-stripe minnow Galaxiella nigrostriata, (Galaxiidae) in an acidic, black-water lake in Melaleuca Park near Perth, Western Australia
}

\author{
Kimberly D. Smith ${ }^{1,2}$, Brenton Knott ${ }^{1}$ and Edyta J. Jasinska ${ }^{1,3}$ \\ ${ }^{1}$ Department of Zoology, The University of Western Australia, \\ 35 Stirling Highway, Crawley, WA 6009, Australia. \\ ${ }^{2}$ Present address: Murdoch University Centre for Fish and Fisheries Research, \\ Division of Science and Engineering, School of Biological Sciences and Biotechnology, \\ Murdoch University, Murdoch, WA 6150, Australia: email: ksmith@central.murdoch.edu.au \\ ${ }^{3}$ Present address: Department of Biological Sciences, University of Alberta, AB, T6G 2E9, Canada.
}

\begin{abstract}
Individuals of Galaxiella nigrostriata (Shipway) from acidic, temporary, black-water wetland designated EPP 173 at Melaleuca Park, Ellen Brook, Western Australia, are compared with members from the main area of distribution of the species some $350+\mathrm{km}$ further south in Western Australia. They were found to be similar to the southern populations in size frequency distribution and habitat. Adult fish from EPP 173 were first sampled, and breed, one month later than those from southern sites. Diets of all populations were similar, comprising predominantly microcrustaceans, dipterans and rotifers; however, prey items at the water surface were consumed less commonly by the northern specimens. G. nigrostriata was found to be sensitive to high water temperatures. Laboratory trials showed that the fish cannot tolerate, for more than a few seconds, temperatures $>26^{\circ} \mathrm{C}$ but preferred a temperature of $14.5^{\circ} \mathrm{C}$. The survival of the G. nigrostriata population in EPP 173 is related to the strong thermal stratification which develops on hot days, with the surface water temperature typically reaching values $>26^{\circ} \mathrm{C}$ but overlying cooler bottom water around $15^{\circ} \mathrm{C}$ which provides a cool water refuge for the resident fish population. The northern outlier population in EPP 173 occurs in the path of the urban expansion of Perth and, since it has high intrinsic conservation value, its management for conservation is paramount.
\end{abstract}

Keywords: Black-water, limnology, thermal stratification, Galaxiidae, feeding

\section{INTRODUCTION}

Galaxiella nigrostriata (Shipway, 1953) (Teleostii: Salmoniformes: Galaxiidae) is a small (maximum length $\sim 4 \mathrm{~cm}$ ) teleost from acidic, black-water temporary pools in the extreme southwestern corner of Australia (Figure 1). Galaxiella nigrostriata, Galaxiella munda, Lepidogalaxias salamandroides (Lepidogalaxiidae), and Nannatherina balstoni [Nannopercidae, following the current Family classification of Allen et al., (2002)] are four species of freshwater teleost endemic to southwestern Australia. They have attracted scientific attention because of i) their specialised habitat within a very restricted geographic distribution, and ii) their method of surviving the seasonal drying of their habitats by aestivating in moist subsurface substrates (Christensen 1982; McDowall and Pusey 1983; Berra and Allen 1989, 1991, 1995; Leung 1988; Berra et al. 1989, 1990; Pusey 1989, 1990; Pusey and Stewart 1989; Pusey and Edward 1990; Jaensch 1992; Pen et al. 1993; Martin et al. 1993; Gill and
Neira 1994, Morgan et al. 1996, 1998). Most populations of all four species occur within a narrow strip of peat flats between Augusta and Albany, southwestern Australia, but three species have at least one outlier population (by some 350 $\mathrm{km}$ ) north of Perth (Figure 1). Knowledge of these outlier populations is based on recent records: $G$. nigrostriata near Bunbury (Morgan et al. 1996, 1998) and Melaleuca Park (Knott and Jasinska 1996); Galaxiella munda (McDowall) (Galaxiidae) between Gingin and Muchea (Allen 1982); and Nannatherina bolstoni (Shipway) (Khulidae) at Gingin (Morgan et al. 1996, 1998). The similarity of their disjunct distributions indicates that all three species may once have been more widespread in southwestern Australia.

The northern outlier population of G. nigrostriata occurs in an un-named wetland, designated as EPP 173 (Environmental Protection Policy Map Identification Number) (Hill et al. 1996)] within Melaleuca Park, some $25 \mathrm{~km}$ northeast of Perth, 


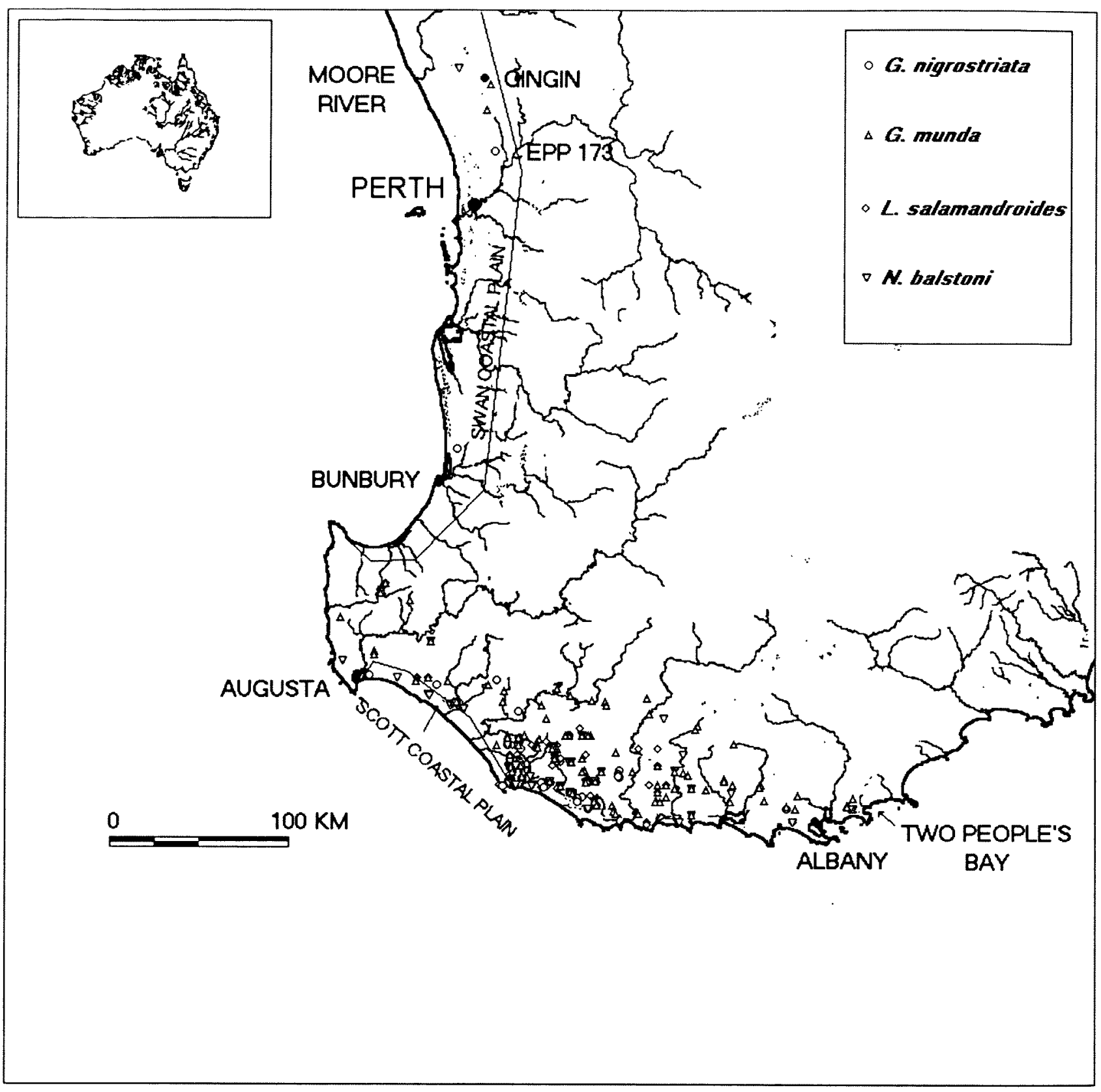

Figure 1 Distribution of Galaxiella nigrostriata, Galaxiella munda, Lepidogalaxias salamadroides and Nannatherina bolstoni within southwestern Australia.

Western Australia. Given the significantly higher day-time temperatures, particularly in summer, and lower annual rainfall at EPP $173\left(31^{\circ} \mathrm{C}\right.$ and $690 \mathrm{~mm}$ p.a., respectively) compared with the area between Augusta and Albany where G. nigrostriata mainly occurs $\left(25^{\circ} \mathrm{C}\right.$ and $1200 \mathrm{~mm}$ p.a., respectively) (meteorological data from the Bureau of Meteorology 1999), aestivation, emergence time, size structure of the population, behavioural biology and diet of G. nigrostriata at EPP 173, were investigated. The results are compared with published data from the southern populations (Pen et al. 1993; Morgan et al. 1996, 1998). Experimental evidence is presented supporting the hypothesis that this northern outlier population has survived due to the specific hydrology of EPP 173. From these findings, an attempt is made to elucidate some of the factors which might limit the distribution of G. nigrostriata. This paper is part of a series of three concerning the outlier population of $G$. nigrostriata. In the other papers in the series, Knott et al. (2002) describe the unique limnological conditions in EPP 173 and Smith et al. (2002) describe the molecular and morphological relatedness between the outlier and southern populations.

This outlier population of $G$. nigrostriata has a strong claim for conservation, but longevity of the population is threatened from three sources: urban expansion, groundwater extraction and highway 
construction. The paper concludes with an appraisal of these threats and the series contributes to knowledge of the southwest Australian piscifauna.

\section{Study Area}

The environment of EPP 173 (31 $42^{\circ} 18^{\prime \prime} \mathrm{S}$; $115^{\circ} 57^{\prime} 41^{\prime \prime} \mathrm{E}$; elevation $50.41 \mathrm{~m}$ AHD (Australian Height Datum); maximum depth $70 \mathrm{~cm} ; 1.5$ ha in area) is described in detail in Knott et al. (2002) but features salient to this paper are briefly summarised here. There is no surface drainage into EPP 173; the only other surface features are a small outflow stream to the east, and a smaller, temporary water body $(\mathrm{Mb})$, contiguous with its northern margin. EPP 173 is fed via a permanent spring seepage which maintains an area of several square metres of boggy peat and shallow $(<11 \mathrm{~cm}$ deep) surface water in late summer and autumn when nearby wetlands are completely dry. EPP 173 and $\mathrm{Mb}$ are continuous at times of peak winter levels of infilling. At EPP 173, water: salinity is low $\left(444 \mathrm{mS} \mathrm{cm}^{-1}\right), \mathrm{pH}$ decreases from 5.5 during inundation to $3.25-3.8$ during the drying phase and colour is very dark ( $\geq 1200$ TCU). Water temperatures reflect the input of $\operatorname{cool}\left(\sim 15^{\circ} \mathrm{C}\right)$ ground-water, and in summer, solar heating. Surface water temperature range from $\sim 27^{\circ} \mathrm{C}$ in summer to $13^{\circ} \mathrm{C}$ in winter (Knott et al. 2002). In winter, the water column is homogenous with respect to temperature but in late spring/early summer, strong thermal gradients develop, for example: $26.7^{\circ} \mathrm{C}$ within $2 \mathrm{~cm}$ of the surface to $15^{\circ} \mathrm{C}$ at $65 \mathrm{~cm}$ depth (15 November, 1995; Knott et al. 2002).

\section{MATERIALS AND METHODS}

\section{Aestivation and emergence}

On May 12, 1996, while the swamp was still dry, a trench (200 cm $\times 40 \mathrm{~cm} \times 60 \mathrm{~cm}$ deep) straddling 2 microhabitat-types [a stand of Baumea articulata (Cyperaceae) and a winter open water habitat] was dug in the peat near the central area of EPP 173. The trench was filled with rainwater and the soil removed was sieved $\left(2 \mathrm{~mm}^{2}\right.$ mesh size) to check for aestivating $G$. nigrostriata. The water-filled trench was swept with a fish net for four hours (11.0015.00 hours) for emergent fish. Root mats in $30 \mathrm{~cm}^{3}$ blocks of soil were removed and submerged in aquaria to observe any fish emergence from that microhabitat. In late May, 1996, leaf litter, the underside of logs, as well as four blocks of sandy/ peat substrate $(40 \mathrm{~cm} \times 40 \mathrm{~cm} \times 60 \mathrm{~cm}$ deep) from EPP 173 were searched for aestivating fish by sieving the detritus. To record where fish aestivated and to exclude the possibility that the fish recolonised EPP 173 each year from nearby refuges, for example by swimming upstream through the outflow channel, EPP 173 was isolated from the small auxiliary swamp, Mb, by a $30000 \times 40 \mathrm{~cm}$ fence of $1 \mathrm{~mm}^{2}$ mesh, supported by star-pickets and inserted $10 \mathrm{~cm}$ into the substrate, and from the outflow stream $6 \mathrm{~m}$ from EPP 173 by a fence of the same mesh.

\section{Size structure}

Low numbers of animals were collected from EPP 173 to minimise the impact on the small $G$. nigrostriata population. The same individuals were used in as many aspects of the study as possible. A sample of $G$. nigrostriata large enough to construct size frequency histograms was collected on August 19 and September 19, 1996. Fish were anaesthetised in $0.015 \%$ benzocaine solution. Total length (snout to end of tail fin) was measured using dial vernier callipers $(0.1 \mathrm{~mm}$ increment). Only recently killed or anaesthetised fish were measured to prevent errors due to deterioration of the specimens.

\section{Diet}

Sample sizes for diet analyses are low because preserving specimens for this purpose precluded their use in other components of the study. Stomach contents were analysed as follows: numbers (+ sampling date), ex EPP 173: 3 adults (26 October, 1995); 12 larvae (6.7-13.3 mm) (19 August, 1996); 12 larvae and juveniles (7.08-20.72 mm) (1 October 1996); ex pools along Chesapeake Road, southeast of Northcliffe ( $\left.34^{\circ} 42^{\prime} \mathrm{S}, 116^{\circ} 07^{\prime} \mathrm{E}\right)$ : 2 adults (July, 1996); 6 (adults) (9 September, 1996). The stomach contents were identified using dissecting and compound microscopes. The diets were analysed by frequency of occurrence, describing the relative contributions of each kind of prey to the total number of prey-items within each stomach.

\section{Laboratory experiments}

Two experiments were conducted to compare the behaviour of $G$. nigrostriata from EPP 173 in aquaria with and without an established thermal gradient. Two un-aerated aquaria measuring $60 \times 25.5 \times 30.5$ $\mathrm{cm}$ (length $x$ width $x$ depth), were filled to a depth of $28 \mathrm{~cm}$ with water from EPP 173 (collected in August 1996) and placed in a controlled temperature room at $17.5^{\circ} \mathrm{C}$. Two treatments were established, a control and an experimental. In the control treatment, the water column was only slightly stratified with respect to temperature, $16.5^{\circ} \mathrm{C}$ at the bottom, varying between 17.0 and $19.5^{\circ} \mathrm{C}$ at the surface due to the heating effect from the light source. In the experimental treatment, a more pronounced temperature gradient was established by placing an aquarium heater (Tronic 200 Watt) horizontally and $1 \mathrm{~cm}$ below the water surface, whilst standing the aquarium on brick supports within an ice bath; the ice was maintained level with the bottom of the aquarium. In both, a 
100 Watt light source was suspended $15 \mathrm{~cm}$ above the water surface to maintain constant illumination levels between treatments. Water temperature was measured using a $0-50^{\circ} \mathrm{C}$ E-Mill Precision thermometer $\left(0.1^{\circ} \mathrm{C}\right.$ graduated increments). In the experimental treatment, water temperatures $2 \mathrm{~cm}$ below the surface ranged between 24.5 and $28.0^{\circ} \mathrm{C}$; water temperatures $2 \mathrm{~cm}$ above the bottom ranged between 8.0 and $9.5^{\circ} \mathrm{C}$.

In the first experiment, fish were released individually at the surface from a net into the stratified aquarium to acclimatise for 1 hour. The position of each fish relative to the bottom of the aquarium was then recorded at three random times during the second hour. The same fish was then transferred to the control aquarium and the same procedure repeated. Eleven replicates were performed over 2 days, using a different fish in each trial. The three scores from each trial were averaged to give a mean position within the temperature gradient for each fish in each treatment. The data were analysed using a paired two-tailed t-test with 11 degrees of freedom. The second experiment compared the amount of time fish spent feeding at the surface in each temperature treatment. Collembola, which are a natural component of the diet of this species, were collected from a suburban wetland near Perth. Twelve trials were conducted using 12 different fish and the sequence of treatments to which each fish was subjected was alternated in each trial. After fish had acclimated for one hour, a $2 \mathrm{~cm}^{2}$ aggregation of Collembola estimated to consist of approximately 400 animals, was added to the aquarium surface. For 15 minutes the amount of time each fish spent within $3 \mathrm{~cm}$ of the water surface was recorded.

\section{RESULTS}

\section{Aestivation and emergence}

In 1996, no fish were recovered in EPP 173, regardless of the search method, prior to inundation following the onset of winter rains. The first specimens in 1996, 4 adults (length, $25.5-34.0 \mathrm{~mm}$ ), were recorded on June 29 when the water depth in the lake at the site of permanent seepage was 64 $\mathrm{cm}$. On August 19, 1996, $17 \mathrm{G}$. nigrostriata 0+ recruits (length, $6.7-13.3 \mathrm{~mm}$ ) and on September 19, 1996, 35 G. nigrostriata 0+ recruits (length, 7.0 $20.7 \mathrm{~mm}$ ) were collected from EPP 173 and also from $\mathrm{Mb}$, when it was still separate from EPP 173. No G. nigrostriata were caught in the outflow stream downstream from the fence.

\section{Size frequency}

Seventeen specimens from EPP 173 (length, 6.7 $13.3 \mathrm{~mm}$ ) collected 19 August, 1996, and 35

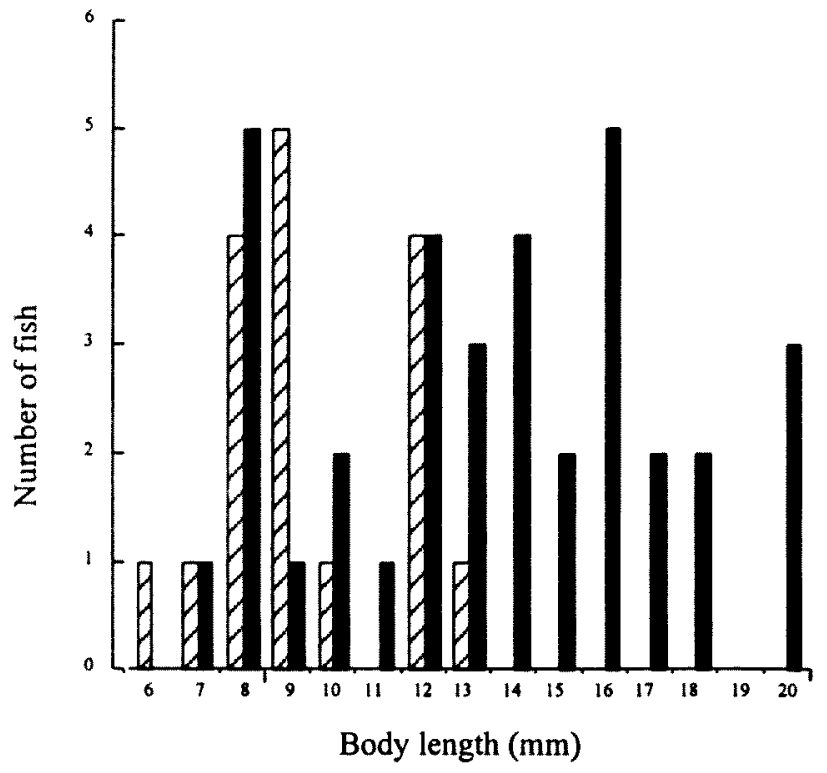

Figure 2 Length-frequency histogram of two samples of G. nigrostriata from EPP 173 collected in 1996. August, hatched bars; September, solid bars.

specimens (length, $7.0-20.7 \mathrm{~mm}$ ) collected 19 September, 1996, were all 0+ recruits (Figure 2).

\section{Diet}

A total of 11 prey taxa were recorded, eight from the stomachs of specimens from EPP 173 (Figure 3) and seven from the Chesapeake Road specimens (Figure 4). Comparisons of the stomach contents

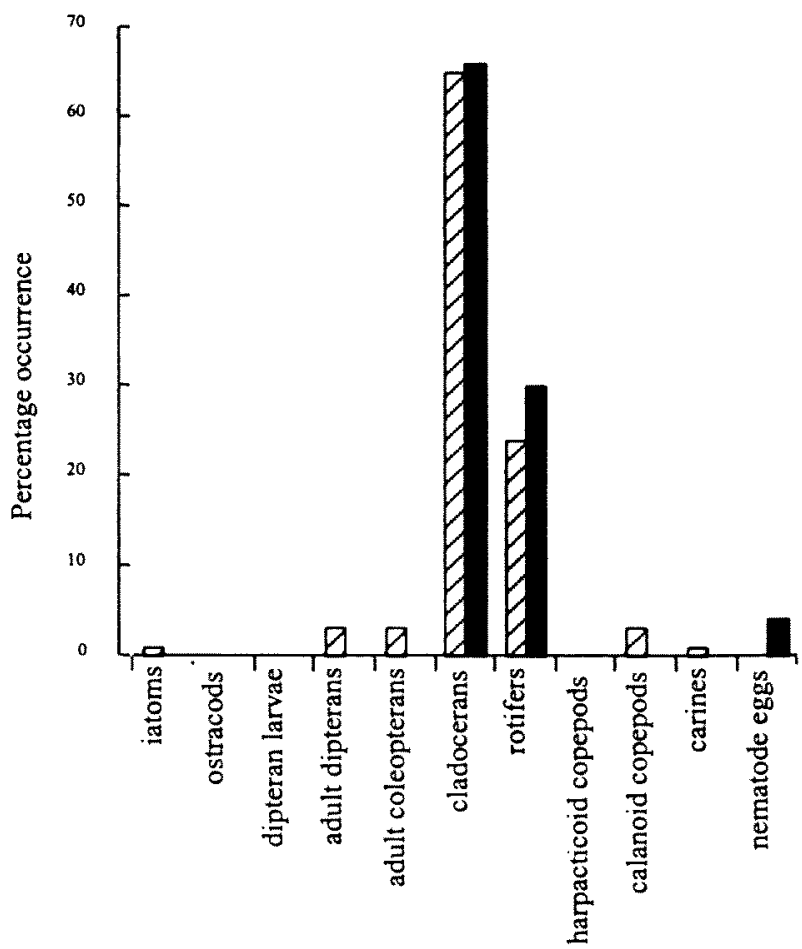

Figure 3 Combined percentage occurrence of prey taxa in stomachs of G. nigrostriata from EPP 173. Hatched, October 1995. Solid, August 1996. 


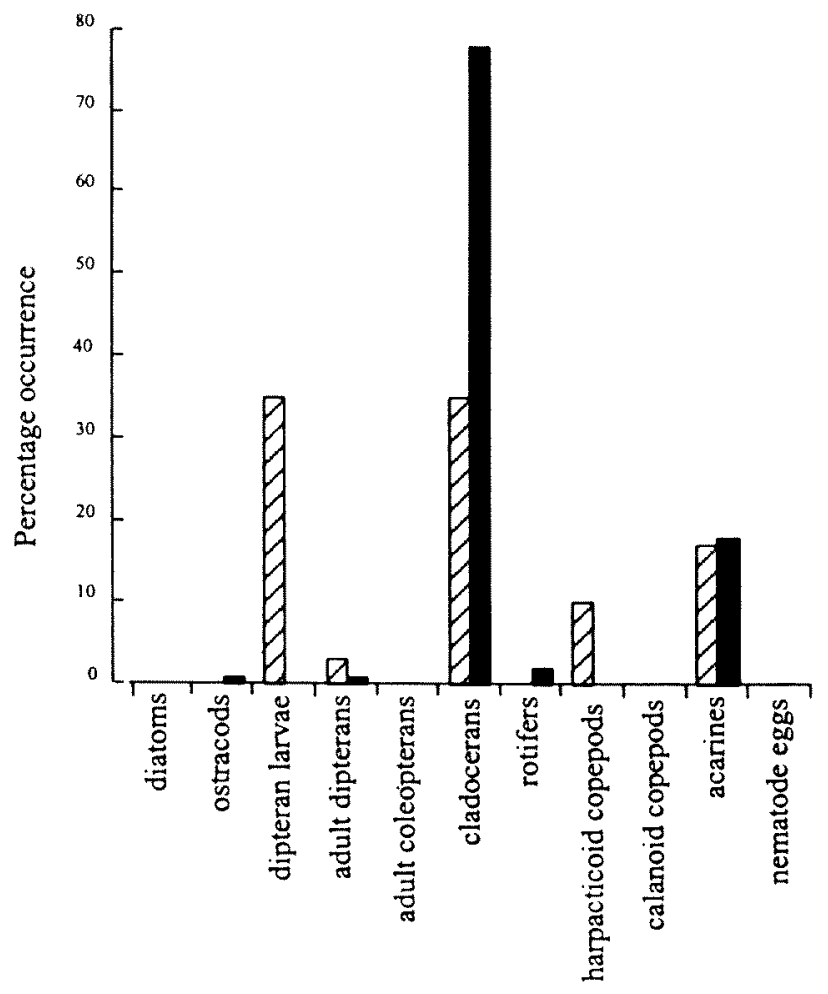

Figure 4 Combined percentage occurrence of prey taxa in G. nigrostriata from Chesapeake Road in the lower southwest during 1996. Hatched, July. Solid, September.

from both sites reveal no marked differences in abundance and diversity of prey consumed. Cladocerans, followed by rotifers (EPP 173) and terrestrial insects (Chesapeake Road), were the prey most commonly ingested at both sites. Harpacticoid copepods and acarines also occurred consistently in the diet of the southern fish. Other prey items, such as diatoms and calanoid copepods were recorded infrequently.

\section{Laboratory experiments}

Fish were consistently observed at greater depths in the stratified, than in the control, aquaria (Table 1).

Table 1 Average distance $(\mathrm{cm})$ of $G$. nigrostriata from the bottom of the water column in stratified and unstratified (control) aquaria.

\begin{tabular}{ccc}
\hline Trial & Stratified & Unstratified \\
\hline 1 & 3.7 & 17.5 \\
2 & 3.7 & 8.7 \\
3 & 5.7 & 12.3 \\
4 & 4.3 & 7.5 \\
5 & 4.3 & 16.7 \\
6 & 4.3 & 7.7 \\
7 & 4.5 & 6.7 \\
8 & 2.7 & 16.0 \\
9 & 2.5 & 4.8 \\
10 & 2.3 & 14.0 \\
11 & 5.7 & 2.7 \\
Mean & $4.0 \pm 1.2$ & $10.4 \pm 5.1$ \\
\hline
\end{tabular}

Table 2 Time (seconds) spent feedi, within $3 \mathrm{~cm}$ of the water surface in the stratified (S) and unstratified (C) aquaria.

\begin{tabular}{lccc}
\hline Trial & First treatment & Stratified & Control \\
\hline 1 & S & 1 & 150 \\
2 & $\mathrm{C}$ & 0 & 516 \\
3 & $\mathrm{~S}$ & 0 & 170 \\
4 & $\mathrm{~S}$ & 3 & 201 \\
5 & $\mathrm{C}$ & 2 & 185 \\
6 & $\mathrm{~S}$ & 0 & 271 \\
7 & $\mathrm{~S}$ & 0 & 0 \\
8 & $\mathrm{C}$ & 0 & 63 \\
9 & $\mathrm{~S}$ & 7 & 28 \\
10 & $\mathrm{C}$ & 1 & 0 \\
11 & $\mathrm{~S}$ & 1 & 9 \\
12 & $\mathrm{C}$ & 17 & 205 \\
Mean \pm S. E. & & $3 \pm 5$ & $150 \pm 149$ \\
\hline
\end{tabular}

The mean position of fish in the stratified aquarium was $4.0 \mathrm{~cm}( \pm 1.2)$ from the bottom of the water column, where water temperature was $14.5^{\circ} \mathrm{C}$. The average position of fish in the control aquarium, where thermal stratification was not established, was $10.4 \mathrm{~cm}( \pm 5.1)$ from the bottom at a water temperature of $17.0-18.0^{\circ} \mathrm{C}$. The two results were significantly different $(p=0.003$, d.f. $=10$; paired two-tailed $t$-test with 11 degrees of freedom).

Similarly, fish in the control aquarium spent significantly more time feeding at the surface than did those in the stratified aquarium (Table 2). Most fish in the control aquarium frequently remained within the top $3 \mathrm{~cm}$ of the water column (average time 2.5 minutes), feeding constantly on prey floating at the water surface throughout the 15 minute trial period and making no attempt, subsequently, to increase their depth. In marked contrast, the fish in the stratified aquarium spent most of the time near the bottom of the water column, darting to the water surface to capture prey and then quickly returning to the bottom. The average time each fish spent within $3 \mathrm{~cm}$ of the water surface was less than 3 seconds, with the exception of one trial where the fish remained in the epilimnion for up to 7 seconds.

\section{DISCUSSION}

Although many wetlands of the Swan Coastal Plain have been degraded (Wrigly et al. 1988; Halse 1989 ) or lost (estimated as $70 \%$, Halse 1989) under the impact of the European presence in Western Australia, numerous wetlands remain and 40 in the vicinity of Perth have been the subject of a major study (summarised in the seven volume series Wetlands of the Swan Coastal Plain edited by S. A. Balla and J. E. Davis, released during the years 1993 - 1996). The occurrence of outlier populations of three species of endemic fish known previously 
only from the extreme southern area of Western Australia probably indicates that all three once had wider geographic distributions in the southwestern corner of the State. The comparatively recent discoveries of these outlier populations raise the question of how many more outlier populations may occur, even in close proximity to Perth. It is relevant, therefore, to question what limnological features may have facilitated the survival of $G$. nigrostriata within EPP 173. The main habitat of the Black-stripe minnow is temporary swamps along the coastal strip between Albany and Augusta, with the centre of distribution the peat flats along Chesapeake Road, D'Entrecasteaux National Park (Allen 1982; Morgan et al. 1996; Pen et al. 1993). The northern outlier population in EPP 173 also inhabits an acidic, black-water temporary swamp, but under markedly more stressful (lower rainfall: $690 \mathrm{~mm}$ p.a. compared to $1200 \mathrm{~mm}$ p.a.; higher summer maximum temperature averages: $31^{\circ} \mathrm{C}$ compared to $25^{\circ} \mathrm{C}$ ) climatic conditions.

The presence of surface water throughout summer in EPP 173 is not a critical factor for the persistence of $G$. nigrostriata at this site, since i) no fish have been found in the permanent pool when the major part of the wetland has been dry, and ii) fish were present in $\mathrm{Mb}$ when it had been isolated from EPP 173 by a mesh fence. Nor is the outflow stream involved in the annual recolonisation of EPP 173 by $G$. nigrostriata. The Black-striped minnows within EPP 173 and $\mathrm{Mb}$ presumably aestivate within the boundaries of the swamp beds and therefore comprise a locally resident population.

Clearly acid, temporary waters are important for defining the ecophysiological niche of $G$. nigrostriata. The results presented here indicate two other features essential for the survival of this galaxiid in EPP 173: one, the input of cool $\left(14^{\circ} \mathrm{C}\right)$ ground water; two, the high colour of the water, through which a strong temperature gradient is established during the hot days at the base of which is a refuge of cool water (Knott et al. 2002). Temperature stratification has also been documented for Lake Jandebup, $<10 \mathrm{~km}$ to the west of EPP 173, but in that lake the temperature gradient does not exceed $6.6^{\circ} \mathrm{C}$ (Ryder and Horwitz 1995), possibly due to the water being only slightly coloured, with values between 2 to $17 \mathrm{~g}_{440} \mathrm{~m}^{-1}$ (Sommer and Horwitz, 1999). The extremely dark (>1200 TCU) water of EPP 173 facilitates the development of a strong thermal stratification on hot days. When Black-striped minnows are netted and lifted through the warm epilimnion, they die instantly. Consistent with this is the observation that on hot days no specimens of G. nigrostriata have been observed near the water surface. This stratification, with the refuge of comparatively cool bottom water is undoubtedly one of the important factors which has enabled G. nigrostriata to persist in EPP 173 despite the high air temperatures.

The heat stress experiment shows that $G$. nigrostriata from EPP 173, when provided with a cool water refuge, avoid water temperatures $>26^{\circ} \mathrm{C}$ which effectively excludes them from the surface layers. However, G. nigrostriata in D'Entrecasteaux National Park have been recorded in drying pools at a temperature of $34^{\circ} \mathrm{C}$ (Morgan et al. 1996, 1998). It is unclear from the available data whether there are different responses to temperature shown by the minnows from the two areas, however one might suspect $a$ priori that gravid females or juveniles may be particularly susceptible to thermal stress. Thermal avoidance may also reflect scope for exercising choice: Galaxias maculatus avoids a plume of warm water discharged from a power station (Boubee et al. 1991). The predation rate on flying ants and adult Diptera, i.e. on terrestrial insects, varied seasonally in the southern populations [from $50 \%$ (in winter) to $20 \%$ (in summer) (Pen et al. 1993)] but there was limited predation on terrestrial insects at EPP 173 ( $<5 \%$ of total stomach contents). Results from the heat stress and feeding experiments indicated that the minnows can change their feeding behaviour in response to adverse temperatures at the water surface.

The effects of the warmer, dryer climate experienced at EPP 173 compared with the climate throughout the main zone of distribution of the species are evident in delays in the time of emergence of the larvae and of spawning. On July 8 1991, the predominant size class of 0+ recruits was $5-10 \mathrm{~mm}$ in the lower southwest (Pen et al., 1993). In 1996, this did not become the modal size class at EPP 173 until late August. Furthermore, in September 1991, 0+ recruits ranged up to $35 \mathrm{~mm}$ in length in the lower southwest, but during this month in 1996 at EPP 173, no specimens larger than $20 \mathrm{~mm}$ were recorded. Spawning commenced in June in the southern populations in 1991 but in 1996 probably did not commence until July at EPP 173, since gravid adults were not captured there until late June. Although different years have been compared, and conclusions have been based on small sample sizes, we have not detected any evidence for biological divergence between the EPP 173 and the more southern $G$. nigrostriata populations other than the delayed emergence and subsequent spawning by adults .

We think it unlikely that EPP 173 was the only wetland of the central Swan Coastal Plain to have harboured G. nigrostriata until comparatively recent historical times, since dark water swamps are believed to have been well represented in wetlands of the Swan Coastal Plain before the arrival of Europeans. Now, however, these swamps occur primarily along the lower south coast. Most of the Swan Coastal Plain wetlands subjected to high 
levels of disturbance are now colourless, open water systems from which $G$. nigrostriata may have been excluded by the loss of cool, bottom water refuges stemming from reduction in both colour and thermal stratification. Clearly, the population of $G$. nigrostriata at EPP 173 has high conservation status and stringent management protocols need to be established to conserve the population. Management of the groundwater supply and also of the vegetation and buffer zones surrounding the wetland will be essential.

EPP 173 is threatened from three sources. 1). The urban population in the immediate vicinity is expected to increase from 8200 residents (1993) to $95000(2021+)$ (Department of Planning and Urban Development 1994). 2). Wetlands within Melaleuca Park are supported by seepage from the Gnangara Mound, an extensive unconfined aquifer which currently provides nearly $40 \%$ of the public water supply for Perth, a figure likely to increase to $>50 \%$ over the next 15 years (Department of Conservation and Land Management 1999). Increasing groundwater abstraction has resulted in the loss of wetlands on the Swan Coastal Plain by the lowering of the water table and hydraulic heads of springs and seepages and although EPP 173 is identified as an ecologically significant wetland to be managed to an Environmental Water Requirement of $0.1 \mathrm{~m}$ above ground level (Water and Rivers 1997), experience suggests that it will be difficult to sustain this objective against climatic vagaries and the demand over time for water. 3). Of four alignments considered for the proposed Perth Darwin National Highway, that most recently preferred is for construction of a highway $<3 \mathrm{~km}$ east of EPP 173 (Department of Planning and Urban Development 1994); at present, the wetland, $100 \mathrm{~m}$ from the edge of Melaleuca Park gains some protection from frequent human visitation by the low intensity rural buffer further the east, with the nearest house some $440 \mathrm{~m}$ distant. The site will require management to preserve conditions for the water supply to be maintained, and for the water to continue stratifying on warm days, including maintenance of the vegetation buffer against wind mixing (Knott et al. 2002).

\section{ACKNOWLEDGEMENTS}

Sharon Stratico and Jeff Kite, Water and Rivers Commission, Western Australia played an important role in the discovery of the population of G. nigrostriata at Melaleuca Park; their help throughout this study is gratefully acknowledged. We also thank Gretchen Pianka for hours of assistance in the field, Luke Pen and Howard Gill for editorial comment, and Dave Morgan for compiling the map used as Figure 1. This work was supported by funding from The University of
Western Australia, and the Water and Rivers Commission, Perth.

\section{REFERENCES}

Allen, G.R. (1982). A Field Guide to Inland Fishes of Western Australia. Western Australian Museum. $86 \mathrm{pp}$.

Allen, G.R., Midgley, S.H. and Allen, M.R. (2002) A Field Guide to Freshwater Fishes of Australia. Western Australian Museum/C.S.I.R.O., Perth.

Berra, T.M., and Allen, G.R. (1989). Burrowing, emergence, behaviour and functional morphology of the Australian salamanderfish, Lepidogalaxias salamandroides. Fisheries 14: 2-10.

Berra, T.M., and Allen, G.R. (1991). Population structure and development of Lepidogalaxias salamandroides (Pisces : Salmoniformes) from Western Australia. Copeia 1991: 845-850.

Berra, T.M., and Allen, G.R. (1995). Inability of salamanderfish, Lepidogalaxias salamandroides, to tolerate hypoxic water. Records of the Western Australian Museum 17: 117.

Berra, T.M., Sever, D.M. and Allen, G.R. (1989). Gross and histological morphology of the swimbladder and lack of accessory respiratory structures in Lepidogalaxias salamandroides, an aestivating fish from Western Australia. Copeia 1989: 850-856.

Berra, T.M., Scott, G., Allen, G.R. and Schmitt, L.H. (1990). Genetic variation in the salamanderfish (Lepidogalaxias salamandroides) and its relationship to other salmoniform fishes. Isozyme Bulletin 23: 103.

Boubee, J.A., Schicker, K.P. and Stancliff, A.G. (1991). Thermal avoidance in inanga, Galaxias maculatus (Jenyns), from the Waikato River, New Zealand. New Zealand Journal of Marine and Freshwater Research 25: 177-180.

Christensen, P. (1982). The distribution of Lepidogalaxias salamandroides and other small fresh-water fishes in the lower southwest of Western Australia. Journal of the Royal Society of Western Australia 65: 131-141.

Department of Conservation and Land Management (1999). Gnangara Park: A concept plan to identify the main issues and discuss the proposed directions for the Park. Technical working group publication of the Department of Conservation and Land Management, Western Australia.

Department of Planning and Urban Development (1994). North east corridor structure plan. Department of Planning and Urban Development, Perth, Western Australia.

Gill, H.S. and Neira, F.J. (1994). Larval descriptions of three galaxiid fishes endemic to south-western Australia: Galaxias occidentalis, Galaxiella munda and Galaxiella nigrostriata (Salmoniformes: Galaxiidae). Australian Journal of Marine and Freshwater Research 45. $1307-1317$.

Halse, S.A. (1989). Wetlands of the Swan Coastal Plain past and present. In G. Lowe (ed.) Proceedings of the Swan Coastal Plain Groundwater Conference: 105-112. Western Australian Water Resources Council, Perth.

Hill, A.L., Semeniuk, C.A., Semeniuk, V. and Del Marco, A. (1996). Wetlands of the Swan Coastal Plain. Vol. 1: 
Wetland Mapping, Classification and Evaluation - Main Report. Vol. 2: Wetland Mapping, Classification and Evaluation - Wetland Atlas. Report prepared for the Water and Rivers Commission and the Department of Environmental Protection, Western Australia.

Jaensch, R.P. (1992). Fishes in wetlands of the south coast of Western Australia. Unpublished technical paper, Department of Conservation and Land Management of Western Australia, Perth.

Knott, B. and Jasinska, E.J. (1996). Melaleuca swamp and Edgecombe spring, Ellenbrook, Western Australia. Report to the Water and Rivers Commission, Western Australia. 12 pp.

Knott, B., Jasinska, E.J. and Smith K.D. (2002). Limnology and aquatic fauna of EPP 173, Melaleuca Park, refuge for an outlier population of the Black-stripe minnow Galaxiella nigrostriata (Pisces: Galaxiidae) in southwestern Australia. Records of the Western Australian Museum 21: 291-298.

Leung, L.K.P. (1988). Ultrastructure of the spermatozoan of Lepidogalaxias salamandroides and its phylogenetic significance. Gamete Research 19: 41-49.

Martin, K.L.M., Berra, T.M. and Allen, G.R. (1993). Cutaneous aerial respiration during forced emergence in the Australian salamanderfish, Lepidogalaxias salamandroides. Copeia 1993: 875-879.

McDowall, R.M. and Pusey, B.J. (1983). Lepidogalaxias salamandroides Mees - a redescription, with natural history notes. Records of the Western Australian Museum 11: 11-23.

Morgan, D.L., Gill, H.S. and Potter, I.C. (1996). The Distribution of Freshwater Fish in the Southwestern Corner of Australia. Water Resource Technical Series Report WRT 4, Water and Rivers Commission. 26 pp.

Morgan, D.L., Gill, H.S. and Potter, I.C. (1998). The distribution, identification and biology of freshwater fishes in south-western Australia. Records of the Western Australian Museum. Suppl. No. 56. 97 pp.

Pen, L.J., Gill, H.S., Potter, I.C. and Humphries, P. (1993). Growth, age composition, reproductive biology and diet of the Black-stripe minnow Galaxiella nigrostriata (Shipway), including comparisons with the other two Galaxiella species. Journal of Fish Biology 43: 847-863.
Pusey, B.J. (1989). Aestivation in the teleost fish Lepidogalaxias salamandroides Mees. Journal of Comparative Biochemistry and Physiology 92A: 137-138.

Pusey, B.J. (1990). Seasonality, aestivation and the life history of the salamanderfish Lepidogalaxias salamandroides (Pisces: Lepidogalaxidae). Environmental Biology of Fishes 29: 15-26.

Pusey, B.J. and Edward, D.H.D. (1990). Structure of fish assemblages in waters of the southern acid peat flats, south-western Australia. Australian Journal of Marine and Freshwater Research 41: 721-734.

Pusey, B.J. and Stewart, T. (1989). Internal fertilisation in Lepidogalaxias salamandroides Mees (Pisces: Lepidogalaxiidae). Zoological Journal of the Linnean Society 97: 69-79.

Ryder, D.S. and Horwitz, P. (1995). Diurnal stratification of Lake Jandabup, a coloured wetland on the Swan Coastal Plain, Western Australia. Journal of the Royal Society of Western Australia 78: 99-101.

Smith, K.D., Pen, L.J. and Knott, B. (2002). Genetic and morphological study of the Black-stripe minnow Galaxiella nigrostriata (Shipway, 1953) (Salmoniformes: Galaxiidae), including a disjunct population near Perth, Western Australia. Records of the Western Australian Museum 21: 285-290.

Sommer, B and Horwitz, P (1999). Annual report for the wetland macro-invertebrate monitoring program of the Gnangara Mound Environmental Monitoring Project. Summer/autumn 1997 - 1998, spring 1998 and summer/ August 1998 - 1999. Final report to the Water and Rivers Commission of Western Australia. 61pp.

Water and Rivers Commission (1997). East Gnangara Environmental Provisions Plan. Public Environmental Review. 154 pp.

Wrigley, T.J., Chambers, J.M. and McComb, A.J. (1988). Nutrient and gilvin levels in waters of Coastal Plain wetlands in an agricultural area of Western Australia. Australian Journal of Marine and Freshwater Research 39: 685-694.

Manuscript received 25 July 2001; accepted 29 May 2002 